\title{
THE USAGE OF ARTIFICIAL NEURAL NETWORKS IN MICROBIAL WATER QUALITY MODELING: A CASE STUDY FROM THE LAKE IZNIK
}

\author{
KATIP, A. \\ Department of Environmental Engineering, Faculty of Engineering, Uludag University \\ Görükle Campus, 16059 Bursa, Turkey \\ (e-mail: aballi@uludag.edu.tr; phone:+90-224-294-0918) \\ (Received $12^{\text {th }}$ Mar 2018; accepted $12^{\text {th }}$ Jun 2018)
}

\begin{abstract}
The aim of this study was to develop faecal pollution model structures with artificial neural networks (ANNs) for cost-effective lake water quality management studies. In this study 5 artificial neural networks model structures were applied to predict the Faecal coliform concentrations for 4 different coast areas "Göllüce, İnciraltı, Darka, Orhangazi" and all data of the coasts in Lake İznikTurkey. The Levenberg-Marquardt and backpropagation algorithm was proposed for feed-forward neural networks training. According to performance functions root mean squared error (RMSE), neural network model structures provided acceptable results. Correlation values $(\mathrm{R})$ were found between 0.590 and 0.999 . Increasing the number of hidden layer in the model structures was not raised the model efficiency in each trial. Type and number of input parameters were more effective for some model efficiency. Increasing the number of hidden layer and inputs in the model structures did not raise the model efficiency in each trial. Because depending on the numbers and chemical compositions of the substrates in the lake water microorganism's metabolism and their growth rates could be influenced differently and the larger error values of the modeling results determined in Göllüce and Orhangazi Coasts which influenced by pollution sources. Water quality modeling studies and increasing of monitoring would provide more productive results for protection and management of coastal.
\end{abstract}

Keywords: faecal pollution, mathematical modeling, deep lake, water management, Turkey

\section{Introduction}

One of the main elements that compose the rich biodiversity in the world and Turkey is wetlands. While wetlands of different qualifications increase the ecosystem diversity on one hand, the species using these wetlands raise the species' and genetic diversity on the other hand (Karadeniz et al., 2009). However, wetlands, especially lakes, are considered to be potential agriculture-residential-industrial areas in the development plans for years because of their high values. Wetlands are polluted by domestic, industrial and agricultural pollutants, and thus their biological diversities are destroyed (Oktem et al., 2012).

Contaminations of the environment with pathogen, hazardous and toxic chemicals are the major problems facing the industrialized nations and urbanized regions today. Microbial pollution in coastal and wetland areas is quite important for human and other species (Cordier et al., 2014). Particularly, pathogens, which include bacteria, viruses and protozoans, can come from a variety of point and nonpoint sources. For over a century, bacterial indicator organisms have been used in the USA to assess the presence of faecal contamination, and consequently pathogens, in drinking and bathing waters (NRC, 2004). Commonly used indicators are total coliform, faecal coliform, faecal streptococci, Escherichia coli and Enterococcus (Mas and Ahlfeld, 2009).

Artificial Neural Networks studies starting in 1940s are performed in hydrology, meteorology, ecology and water quality fields (Morid et al., 2007; Ranković et al., 
2010; Kim and Valdes, 2003; Partal and Kişi, 2007; Reimer and Sodoudi, 2004; Mishra and Desai, 2006; Belayneh and Adamowski, 2012). Several lake water quality studies were related to especially phytoplankton production, algal blooms, dissolved oxygen and other spatial and temporal variability of limnological properties and eutrophication (Soyupak et al., 2003; Karul et al., 2000). Microbial contaminants are non-conservative, irregularly distributed and may even increase in concentration due to growth in the environment. The interrelationship and interactions between microbial communities in water creates additional modeling challenges that have been overcome by applications of ANNs to multi-parameter databases. Important and meaningful results were obtained with modeling of pathogens with ANN (Neelakantan et al., 2002; Brion and Lingireddy, 2003; Mas and Ahlfeld et al., 2007; Ogwueleka and Ogwueleka, 2010; WHO, 2010; Wu et al., 2014).

The purposes of this study were to design and develop ANN model structures for prediction of fecal coliform in order to evaluate microbial contamination and to predict the pollution impact on bathing, agricultural, aquaculture, recreation and tourism areas of Lake İznik as this has national and international importance, and also to observe the differences among the modeling results in the lake coasts occurring due to sewage inputs or nonpoint sources according to relevant environmental conditions. This study would be supportive of data management and could be the basis for basin and coastal management and the early warning system studies for public health. Also, this study was important with regards to international environmental scientific developments because the feed forward neural network (FNN) models could supply cost-effective environmental management tools for the investigation of any monitoring stations and pathogenic pollution.

\section{Materials and methods}

\section{Study area and data}

Lake İznik, the largest lake in the Marmara region and the fifth largest in Turkey, is located between the districts of İznik and Orhangazi in the Province of Bursa. It is located between $40^{\circ} 23^{\prime}$ and $40^{\circ} 30^{\prime} \mathrm{N}$ latitudes and $29^{\circ} 20^{\prime}$ and $29^{\circ} 42^{\prime} \mathrm{E}$ longitudes. The lake, which is located $85 \mathrm{~m}$ above sea level, has a length of $32 \mathrm{~km}$ and a maximum width of $12 \mathrm{~km}$. It is about $15-16 \mathrm{~km}$ from the Bay of Gemlik. It has a surface area of $310 \mathrm{~km}^{2}$ and a water volume of 12.2 billion $\mathrm{m}^{3}$. The maximum depth of the lake $(80 \mathrm{~m})$ has been measured near Karacakaya (Ozturk et al., 2005; Yağc1 and Ustaoğlu, 2012). It has 1 outlet, Karsak stream, and 5 inlets, Orhangazi, Kuru, Karasu, Ekinlik and Söloz streams. Karsak stream connects the lake to the Sea of Marmara but it has a number of natural and artificial barriers that marine fishes are unable to cross (Özuluğ, et., al., 2005).

Lake İznik, one of the 76 wetlands of international importance in Turkey, is a natural protected (NP) wetland according to the criteria of The Convention on Wetlands of International Importance (The Ramsar Convention) (RAMSAR, 2007). The ecosystem of Lake İznik was declared to be a natural protected area in 1990 and conforms to the international criteria with its characteristics (BGPEFD, 2008) and The Lake İznik and İznik basin had been an area of settlement throughout the history. The archeological findings in the tumulus in İznik depression suggest that human settlement started 7150 years ago. İznik town later became an important cultural center during the Roman, Byzantine and Ottoman empires (Ülgen et al., 2012). 
Moreover, Lake İznik is a significant bird watching area in Turkey; there are eight host and five stationary bird species, 13 in total, in this area (Akpinar et al., 2010). Lake İznik is a significant water resource not only with its water capacity but also in terms of agriculture, industry, water productions and recreational activities for the region (Başar et al., 2004). Therefore pollution monitoring and preservation of the Lake are important nationally and internationally.

Point and nonpoint (diffuse) pollution sources existed in the watershed, which discharge pollutants into the lake. The pollution loading sources of Lake İznik are agricultural, animal, sewage, forest, aerial (Akkoyunlu et al., 2011) and industrial (Oktem et al., 2012). Partially treated and untreated sewage and nonpoint pollution of fertilizers and pesticides from surrounding agricultural areas reached the lake (Akçaalan et al., 2014; Albay and Aykulu, 2002). Lake water is also used for irrigation and the lake is a popular place for recreation during summer months. Around the lake, especially in Orhangazi region in the west banks of the lake, the planless misuse of 1st class farming lands (open to settlement), which are appropriate for irrigation farming, puts the future of the Lake İznik in danger (Meşeli, 2010).

It is a well-known fact that the pollution in Lake İznik increases proportionately to the population growth. The common use of the septic tanks in Orhangazi and Iznik around the lake causes the pollution of the lake to increase. Also there are 45 villages were around the lake and pollution loads of their domestic waste water affects the lake. But a certain amount of the used water (70-90\% in general) is thought to return to the sewages (Oktem et al., 2012). Moreover, Lake İznik is polluted by the waste water of the Orhangazi Industrial Area, the tankages of İznik and Osmangazi, Marmara Birlik Olive Processing Plants in İznik, and by Ispak industrial plants in Orhangazi. Moreover, the lake was under threat because of the small olive oil plants around it and chemistry, automotive, metal and food industry sectors were present in the lake basin (WWF, 2011). Industries using the water of the lake in processing goods discharge their waste water to the lake without sufficient purification. Phosphorus in the industrial pollution was determined to be 3 times higher than that in the domestic waste water; and nitrogen in the industrial pollution was determined to be 1.5 times higher than that in the domestic waste water. In addition Istanbul-Bursa highway passes through Orhangazi on the west coasts of the Lake İznik and this heavy traffic caused air pollution (Oktem et al., 2012).

Several studies investigated the extent of anthropogenic pollution, such as nutrients, lead, and polycyclic aromatic hydrocarbons (PAH) in the sediment of the recent past and identified differences in the spatial distribution and sedimentation history (Franz et al., 2006; Ünlü et al., 2010; Viehberg et al., 2012). The spatial distribution of $\mathrm{Pb}$ indicating anthropogenic pollution sources coincides with elevated concentration in the delta area of the Sölöz stream which feeding of the Lake İznik. Interestingly, Ünlü et al. (2010) identified high concentrations of polycyclic aromatic hydrocarbons in the same area, thus supporting human-induced contamination (Viehberg et al., 2012).

Samples were taken from 4 different stations from 2010 to 2015. Sampling stations and regions were given in Table 1 and features of the sampling stations were as follows:

Göllüce Village is located in the district limits of İznik sub-province. It is on the main road interconnecting with Gemlik and İznik sub-provinces. There are aggregated reeds at the entrance to the lakeside public beach. Inciraltı public beach is nearby the İznik sub-province. The Darka area is a public beach in front the Darka Holiday Village. Orhangazi Area is near the outlet of the Lake and Orhangazi sub-province. All 
sampling stations and regions are in the swimming areas. Location of Lake İznik and sampling stations were shown in Figure 1.

Table 1. Sampling stations and region

\begin{tabular}{c|c|c|c}
\hline Station no. & Sampling regions & Number of data & Coordinates \\
\hline 1 & Göllüce area & 27 & $40^{\circ} 22^{\prime} 56.49^{\prime \prime} \mathrm{N}, 29^{\circ} 35^{\prime} 36.73^{\prime \prime} \mathrm{E}$ \\
2 & İnciraltı area & 27 & $40^{\circ} 25^{\prime} 46.64 " \mathrm{~N}, 29^{\circ} 42^{\prime} 45.24^{\prime \prime} \mathrm{E}$ \\
3 & Darka area & 27 & $40^{\circ} 24^{\prime} 37.25^{\prime \prime} \mathrm{N}, 29^{\circ} 42^{\prime} 12.04^{\prime \prime} \mathrm{E}$ \\
4 & Orhangazi area & 27 & $40^{\circ} 28^{\prime} 50.37^{\prime \prime N}, 29^{\circ} 20^{\prime} 48.76^{\prime \prime} \mathrm{E}$ \\
& Total data & 108 & \\
\hline
\end{tabular}
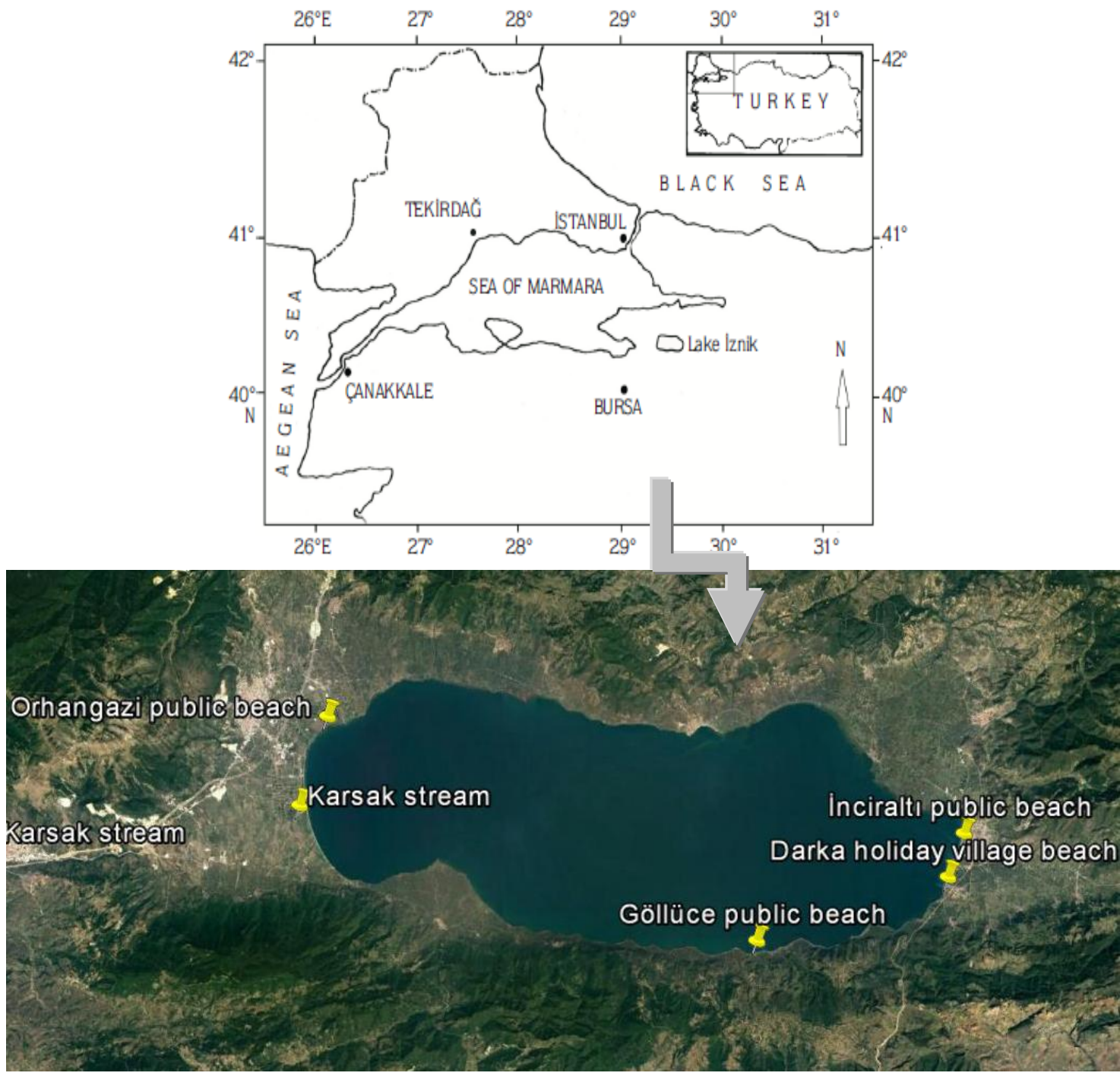

Figure 1. Location of Lake İznik and sampling stations (Ozuluğ et al., 2005 and Google Earth, 2016)

In this study, the microbiological pollution levels of the beaches in Lake İznik were examined with using the data obtained from the Bursa Provincial Directorate of Public 
Health. Total coliform, fecal coliform and fecal streptococci parameters were evaluated and modeled. The samples collected for measurements were taken from $30 \mathrm{~cm}$ below of the surface and put into the polyethylene (PE) single use bottles of $500 \mathrm{~mL}$ volume, kept in the thermo isolated boxes, having cooling bars at $+4{ }^{\circ} \mathrm{C}$, and brought to the lab in $24 \mathrm{~h}$ at the most. Bacterial count were performed by membrane filtration (MF) method and determined as CFU/100 mL (APHA, 1992; YSKY, 2006).

\section{ANN model and training algorithm}

Artificial neural networks are formed of a set of simple elements, the alleged artificial neurons. These elements are inspired by biological nervous systems. Models of neural networks are separated into two categories: feed forward neural networks and recurrent neural networks. Feed forward neural networks propagate data linearly from input to output and they are the most popular and most widely used models in many practical applications. (Hornik, 1991) Showed the feed forward neural network (FNN) with as few as a single hidden layer and arbitrary bounded and smooth activation functions can approximate a continuous nonlinear function (Şen, 2004). The multilayer FNN represented in Figure 2 (Rankovic et al., 2010; Efe and Kaynak, 2002; Okkan and Mollamahmutoğlu, 2010).

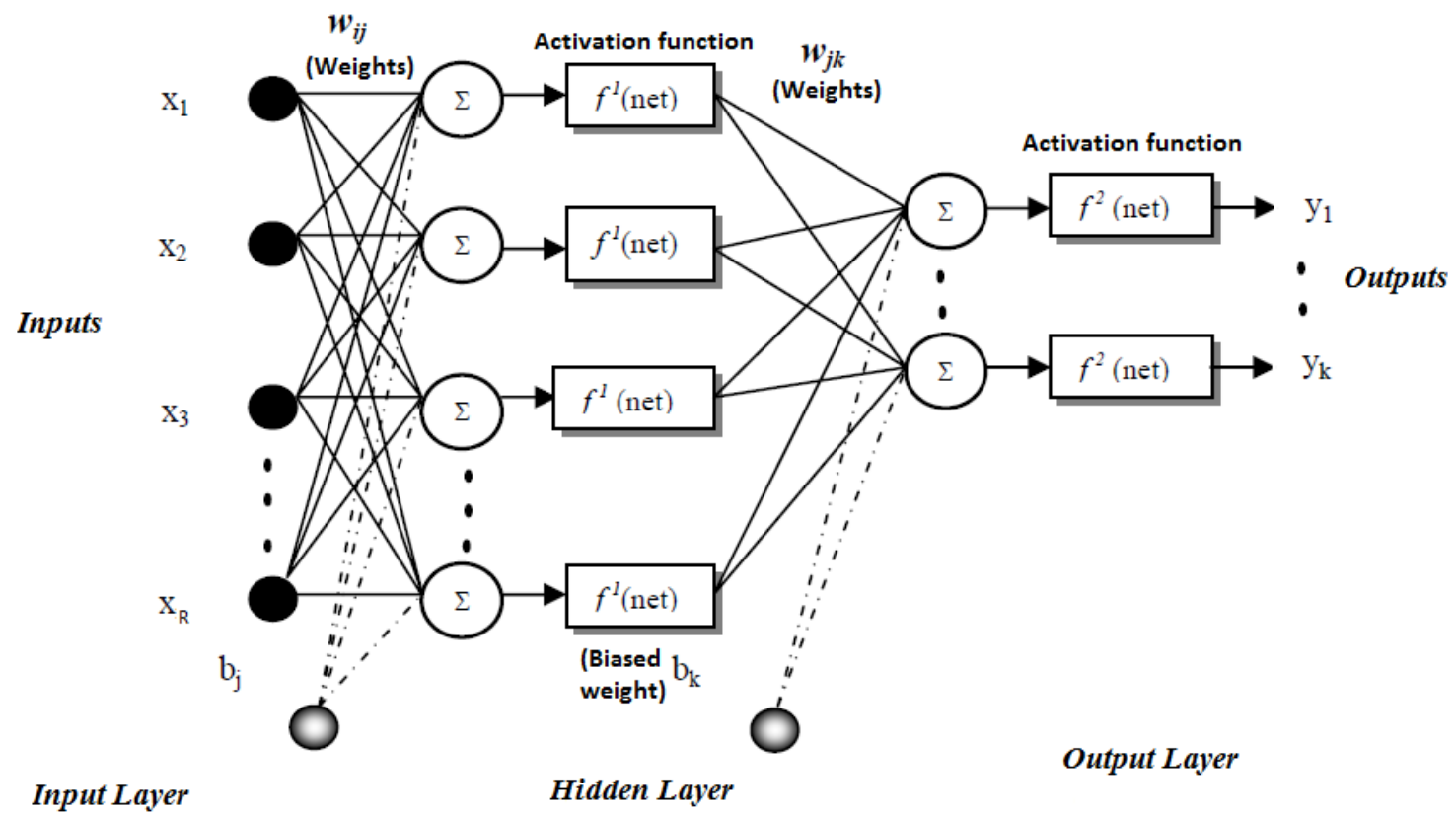

Figure 2. Multi layer feed forward neural network

As shown in Figure 2, the elements constituting ANN are input layer, hidden layers (number of hidden layers are one or might be more), output layer linkages between the layers and linkage weights.

The data of the problem is in the input and output layers. Productivity and importance of information in the input layer are provided with the weights. Net (basis) function expresses that productivity of input data to neuron. For an analytical study, the connection networks are mathematically represented by a basis function $\mathrm{u}(\mathrm{w}, \mathrm{x})$. The 
net value is a linear combination of the inputs and the output of a neuron can be expressed as Equation 1:

$$
\text { out }=f(n)
$$

where (Eq. 2)

$$
n=\sum_{j=1}^{R} w_{j} x_{J}+b
$$

$\mathrm{x}_{1}, \mathrm{x}_{2}, \ldots, \mathrm{x}_{\mathrm{R}}$ are the input signals; $\mathrm{w}_{1}, \mathrm{w}_{2}, \ldots, \mathrm{w}_{\mathrm{R}}$ are the weights of neuron; $\mathrm{b}$ is bias value; and $\mathrm{f}(\cdot)$ is the activation function.

Activation function is a function determining the neuron output with processing the net inputs obtained from net function. The linear and sigmoid are common used activation functions in the construction of artificial neural networks.

An example of the sigmoid is the logistic function, defined by Equation 1:

$$
f(n)=\frac{1}{1+e^{-n}}
$$

Also, as sigmoid function can be used hyperbolic tangent function and it gives the outputs range between [0-1] (Eq. 2; Haykin, 1999):

$$
f(n)=\frac{1-e^{-n}}{1+e^{-n}}
$$

The inputs $\mathrm{x}_{1}, \mathrm{x}_{2}, \ldots, \mathrm{x}_{\mathrm{R}}$ are multiplied by weights $\mathrm{w}_{\mathrm{i}}, \mathrm{j}_{(1)}$ and summed at each hidden neuron i. Then the summed signal (Eq. 5):

$$
n_{i(1)}=\sum_{j=1}^{R} w_{i, j(1)} x_{J}+b_{i(1)}
$$

The node activates a nonlinear function $\mathrm{f}_{(\mathrm{n})}$. The output $\mathrm{y}$ at a linear output node can be calculated as Equation 6:

$$
y=\sum_{i=1}^{z} w_{1, i(2)} \frac{1-e^{-\left(\sum_{i=1}^{R} x_{j} w_{i, j(1)}+b_{i(1)}\right)}}{1-e^{-\left(\sum_{i=1}^{R} x_{j} w_{i, j(1)}+b_{i(1)}\right)}}+b_{1(2)}
$$

where $\mathrm{R}$ is the number of inputs, $\mathrm{z}$ is the number of hidden neurons, wi.j(1) is the first layer weight between the input $\mathrm{j}$ and the $\mathrm{i}^{\text {th }}$ hidden neuron, $w 1, \mathrm{i}(2)$ is the second layer weight between the $i^{\text {th }}$ hidden neuron and output neuron, bi(1) is a biased weight for the ith hidden neuron and b1(2) is a biased weight for the output neuron (Rankovic et al., 2010). 
The learning algorithms using in ANN are heuristics, partial Newton methods, matched gradient methods and Levenberg Marquardt methods. In this study feed forward neural network structure was used and Levenberg Marquardt training algorithm supervised training algorithms was preferred for training. Pupose Levenberg Marquardt algorithm is the least squares calculation method based on maximum neighborly idea (Hagan and Menhaj, 1994). The sum of squared errors of any one of the element in the training set (N number of elements) could be calculated as follows (Eqs. 7 and 8):

$$
\begin{gathered}
E(w)=\frac{1}{2} \sum_{i=1}^{N}\left(y_{m i}-y_{i}\right)^{2}=\frac{1}{2}\left(y_{m}-y\right)^{T}\left(y_{m}-y\right) \\
W=\left[w_{1,1(1)}, w_{1,2(1)}, \ldots, w_{z, R(1)}, b_{1(1)}, b_{2(1)}, \ldots, b_{z(1)}, w_{1,1(2)}, w_{1,2(2)}, \ldots, w_{1, z(2)}, b_{1(2)}\right]^{T}
\end{gathered}
$$

Two number of different hidden layer neuron for each input neurons was tested in this study. This was because; in the recent study were two different approaches used in determining the number of hidden layer neurons. The first approach for a network model which in the $\mathrm{N}$ number of neuron in the input layer: $(\mathrm{N}+1) / 2$ and the second approach: $(2 * \mathrm{~N}+1)$ were introduced (Hagan and Menhaj, 1994; Oğuztürk, 2010).

\section{Performance and sensitivity analysis of ANN}

The performance of the forecasts from the data-driven models was evaluated. The Pearson correlation coefficient is one of the most commonly used performance in selecting proper inputs for the ANN (Rankovic et al., 2010). Correlation coefficient is described as the degree of correlation between the empirical and modeled values (Eq. 9):

$$
r=\frac{\sum_{i=1}^{N_{0}}\left(y_{i}-\bar{y}\right)\left(y_{m i}-\bar{y}_{m}\right)}{\sqrt{\sum_{i=1}^{N_{0}}\left(y_{i}-\bar{y}\right)^{2}} \sum_{i=1}^{N_{0}}\left(y_{m i}-\bar{y}_{m}\right)^{2}}
$$

where $\mathrm{y}_{\mathrm{i}}$ and $\mathrm{y}_{\mathrm{mi}}$ enounce the network output and measured value from the $\mathrm{i}^{\text {th }}$ element; $\overline{\mathrm{y}}$ and $\bar{y}_{m}$ conceive their average respectively, and $\mathrm{N}_{\mathrm{o}}$ describes the number of measurements.

Another performance measure is mean absolute error (MAE). The MAE is used to measure how close forecasted values are to the observed values. It is the average of the absolute errors. The smaller values of MAE and MSE (mean square error) provide the better performance (Belayneh and Adamowski, 2012). MAE and MSE are estimated as follows (Eqs. 10 and 11):

$$
\begin{aligned}
& M A E=\frac{1}{N_{0}} \sum_{i=1}^{N_{0}}\left|y_{m i}-y_{i}\right|^{2} \\
& M S E=\frac{1}{N_{0}} \sum_{i=1}^{N_{0}}\left(y_{m i}-y_{i}\right)^{2}
\end{aligned}
$$




\section{ANN application}

In this study, the total coliform, fecal coliform and fecal streptococci parameters, which were measured between the years of 2010 and 2015, were modeled. The total number of measurements used in modeling for each parameter was 108 and 27 number of data was evaluated for each of lake coasts and parameters.

The amount of data needed to train a neural network is very much problemdependent. The quality of training data (i.e., how well the available training data represents the problem space) is as important as the quantity (i.e., the number of records, or examples of input-output pairs). The key is to use training data that generally span the problem data space. For relatively small datasets (fewer than 20 input variables, 100 to several thousand records) a minimum of 10 to 40 records (examples) per input variable is recommended for training (NNMP, 2016). The total data number used in ANN modeling studies, related to water quality, ranged from 60 and 442 (Brion and Lingireddy, 2003; Mas and Ahlfeld, 2007; Radojevic et al., 2013). For these reasons the total number of data used in this study is suitable for water quality studies.

In this study, all the ANN model structures were created with the MATLAB ANN toolbox (Matlab, R2015). The tangent sigmoid transfer function was the activation function for the hidden layer, while the activation function for the output layer was a linear function. All the ANN models in this study were trained using the Levenberg Marquardt (LM) back propagation algorithm. The LM back propagation algorithm was chosen because of its efficiency.

All the ANN models the cross validation technique was used to partition the data sets; $80 \%$ of the data was used to train the models, while the remaining $20 \%$ of the data was used to test and validate the models, with $10 \%$ used for testing and $10 \%$ used for validation (Principe et al., 1999; Keskin et al., 2011; Keskin et al., 2009; Belayneh and Adamowski, 2012). In microbiological modeling studies, between 60 and $80 \%$ of the total data were used in training process, between 10 and $20 \%$ were used in test and validation stage (Brion and Lingireddy, 2003; Mas and Ahlfeld, 2007; Radojevic et al., 2013).

The training set was used to compute the error gradient and to update the network weights and biases. The error from the validation set was used to monitor the training process. If the network overfits the data the error in the validation set will begin to rise. The testing data set is an independent data set and is used to verify the performance of the model.

The data based on monthly average values was used in this study and 4 model structure (a, b, c, d) were tested for each 5 model (Model 1-Total data of the Lake, Model 2-Göllüce area, Model 3-İnciraltı area, Model 4-Darka area and Model 5Orhangazi area). The results in the model structures related to ANN modeling experiments with a different number of hidden layers were defined in a comparative way.

In the (a) and (b) model structures total coliform and fecal streptococci and in the (c) and (d) model structures total coliform were chosen as input parameters. In all of the model structures, fecal coliform was selected as output parameter.

Total coliform parameter does not always indicate fecal contamination or the presence of the pathogens in water. Some bacteria, which are non-fecal source, answer to the definition of coliform bacteria. Most of the fecal streptococci bacteria are fecal source and in practice, they are the most important indicator of contamination with human feces. However, certain types and their subtypes are also present in plant 
material. Fecal streptococci rarely grow in contaminated water and are more resistant than coliform bacteria. Fecal coliforms are a subgroup of the total coliform bacteria and are of fecal origin. While total coliforms may be given some permission since they are phytogenetic and soil born, fecal coliforms are allowed to a very limited number of permission (Casadevall and Pirofski, 2014; Alberts et al., 2002). For this reason, Fecal coliform was chosen as an output parameter and modeled with the aim of estimating the sewages containing human and animal waste and providing support to the prevention works afterwards.

\section{Results and discussion}

\section{Water quality and basic statistic of the data set}

According to the "Blue Flag Criteria" (TÜRÇEV, 2013), microbial contaminant levels for the last 4 years are required in order to determine the level of pollution of beaches. Therefore, the measurements performed at the Lake coasts during the swimming season, in other words in summer months, between the years of 2010 and 2015, were evaluated within the context of this study. The results of the measurements were evaluated according to "Table of Criteria for Water Quality Required for Swimming and Recreation in Swimming Water Quality Act" (Table 2).

Table 2. Table of criteria for water quality required for swimming and recreation (YSKY, 2006)

\begin{tabular}{c|c|c}
\hline Parameters & Reference values & Mandatory values \\
\hline Total coliform $/ 100 \mathrm{ml}$ & $\begin{array}{c}1000(2006-2014 \text { years }) \\
500(2015 \text { year })\end{array}$ \\
\hline Faecal coliform $/ 100 \mathrm{ml}$ & $\begin{array}{c}200(2006-2014 \text { years }) \\
100(2015 \text { year })\end{array}$ & 10000 \\
\hline Faecal streptococci $/ 100 \mathrm{ml}$ & 100 & 1000 \\
\hline
\end{tabular}

According to this table; if the measured values are under the reference values, the water is in good quality, between the reference values and mandatory value is in medium quality and above the mandatory value, is in poor quality.

When the variation of microbial pollution in the coastal areas was examined the parameters were changed with good and medium quality. However, according to the values of 2015, faecal coliform and faecal streptococci parameters were found to be in good class and the pollution decreased in the all coasts. It was determined that total coliform and faecal streptococci concentrations were no statistical difference among the months but slight increase in these parameter's concentrations were observed in the each month until late spring to early fall. These parameters could be soil and plant origin. Therefore intensive agricultural activity and rain in these months may increase the concentrations (Akkoyunlu et al., 2011; WWF, 2011). According to the statistical calculations (ANOVA tables) for all of the Lake there was no difference among the months and monitoring stations of the coasts. But the differences among the years for faecal coliform and faecal streptococci parameters were found significant $(p \leq 0.05)$ statistical. According to the ANOVA analysis results for the each station the monthly 
alterations of faecal streptococci in Darka and Orhangazi public beaches were found as significant ( $\mathrm{p} \leq 0.05)$ statistically (Demirci and Can, 2015). Basic statistic of the data set for this water quality and modeling studies was given in Table 3.

Table 3. Basic statistic of the data set

\begin{tabular}{c|c|c|c|c|c}
\hline Coasts & $\begin{array}{c}\text { Parameters } \\
\text { (CFU / 100 ml) }\end{array}$ & Mean & Std & Max & Min \\
\hline \multirow{3}{*}{ Göllüce Public Beach } & Total coliform & 511.148 & 636.474 & 3210 & 5 \\
& Faecal coliform & 135.093 & 132.533 & 521.5 & 2 \\
& Faecal streptococci & 73.537 & 63.613 & 220 & 2 \\
\hline \multirow{3}{*}{ İnciraltı Public Beach } & Total coliform & 310.296 & 315.901 & 1500 & 28 \\
& Faecal coliform & 110.222 & 113.191 & 440 & 7.5 \\
& Faecal streptococci & 65.370 & 89.917 & 420 & 2 \\
\hline \multirow{3}{*}{ Darka Holiday Village } & Total coliform & 310.611 & 301.155 & 1200 & 15 \\
& Faecal coliform & 66.889 & 75.676 & 400 & 2.5 \\
& Faecal streptococci & 51.889 & 62.364 & 250 & 3 \\
\hline \multirow{3}{*}{ Orhangazi Public Beach } & Total coliform & 518.185 & 690.173 & 3300 & 5 \\
& Faecal coliform & 110.259 & 110.555 & 425 & 2 \\
& Faecal streptococci & 78.130 & 92.063 & 400 & 2 \\
\hline \multirow{2}{*}{ Lake } & Total coliform & 412.560 & 520.574 & 3300 & 5 \\
& Faecal coliform & 105.616 & 111.137 & 521.5 & 2 \\
& Faecal streptococcus & 67.231 & 77.799 & 420 & 2 \\
\hline
\end{tabular}

Moreover, the correlation of the three parameters with each other was considered statistically significant $(\mathrm{p}<0.05)$. In previous scientific studies, when the correlation between indicator bacteria has been examined, it has been determined that the numbers of indicator bacteria decreased or increased in parallel with each other (Demirci and Can, 2015; Gürün and Kımıran-Erdem, 2013).

\section{The effect of neural network structure on performance function (RMSE) and model estimation power $(R)$}

The effect of neural network structure by changing of inputs and number of hidden neurons (layer) on model performance was investigated. Root Mean Square Error (RMSE) has been adopted as a measure of performance (as performance function) for comparing the effectiveness of tested structures (Belayneh and Adamowski, 2012; Soyupak et al., 2006). The performance function (RMSE) values and correlation coefficients $(\mathrm{R})$ obtained for training, validation, testing and whole data sets. The model structures and their performance functions (RMSE) values and correlation coefficients (R) of the data sets were presented in Table 4. In all model structures, Faecal coliform was chosen as output parameter.

In "Model 1" all data of Lake İznik a and b structures, total coliform and faecal streptococci parameters were chosen as inputs. These models were run quite efficiently. But RMSE values of model 1-b were smaller than model $1-\mathrm{a}, \mathrm{R}$ correlation numbers of model 1-b were bigger than model 1-a except verification values. Enhancing of hidden 
neuron numbers in Model 1-b was raised to whole data set of $\mathrm{R}$ correlation number. In model $1-\mathrm{c}$ and $\mathrm{d}$ total coliform parameter was selected as input. These models were run efficiently. In model 1-d, hidden neuron numbers were raised. For this reason RMSE values of training and testing stages decreased and these $R$ values and $R$ number of whole data increased. İznik sub-province had advanced biological treatment plant with membrane technology and its sewerage system had completed. But the first stage of the treatment plant was put into use just (BUSKİ, 2016). Even so the treatment plant was not run at full capacity the pollution in the lake decreased (Demirci and Can, 2015). Also the monthly variations of the parameter's concentration was not been considered as statistically significant (Demirci and Can, 2015). This situation could be attributed that the pollution load was not belong to a specific period and point pollution sources disturb the ecological balance of the environment because of their uninterrupted waste inputs and therefore change the competitive environment among microorganisms continuously (Gürün and Kımıran Erdem, 2013). As a consequence, it was estimated that there was some inaccuracy in the model results and $\mathrm{R}$ values were not too high. Bursa Metropolitan Municipality planned to start up the second stage of the biological treatment plants in İznik sub-province. So it was estimated that microbiological and chemical pollution in the Lake would decrease (BBB, 2016).

In Göllüce Coasts "model 2" a and b structures, total coliform and faecal streptococci parameters were inputs as model 1. These models were run efficiently. RMSE values of model 2-a and $\mathrm{b}$ training and testing stages were bigger than model $1-\mathrm{a}$ and $\mathrm{b}$ but verification RMSE values were smaller than model 1 . Also verification $R$ values were bigger than model 1, others not. It was found that the performance of model 2 (Göllüce area) less than model 1 (All Data of the Lake). Livelihood of the village of Göllüce was fruit and vegetable farming, especially olive cultivation. Therefore pesticides and fertilizers polluted this coast as diffuse sources. Moreover entering of domestic wastewater was in this coast because of incomplete sewerage system (LGP, 2016).

Microbial growth on and utilization of environmental contaminants as substrates have been studied by many researchers. Most times, substrate utilization results in removal of chemical contaminant, increase in microbial biomass and subsequent biodegradation of the contaminant (Okpokwasili and Nkweke, 2005). Wastewaters from industrial, municipal and agricultural sources are characterized by presence of mixtures of chemicals. Pollutant mixtures may contain only organic chemicals or may also include inorganic substances such as heavy metals. Co-contamination of natural environments with mixtures of pollutants is an important problem. The removal of one component may be inhibited by other components in the mixture and different conditions may be required to degrade different compounds within the mixture. Strong interactions among components of a pollutant mixture have been reported (Egli, 1995; Klečka and Maier, 1988; Meyer et al., 1984; Saéz and Rittmann, 1993). The utilization pattern can change with different mixture compositions, depending on the chemical nature and concentration of the substrate, oxygen concentration and microbial growth rates. In addition to biodegradation stimulation due to increased growth at low substrate concentrations, stimulation of one compound by another in a mixture can be by induction of catabolic enzymes required for degradation of the second pollutant (Arvin et al., 1989). This mechanism produces simultaneous degradation of pollutants in mixtures and has been reported for pentachlorophenol and chlorinated aromatics, toluene and $p$-xylene (Okpokwasili and Nkweke, 2005). 
Table 4. The model structures and their performance functions (RMSE) values and correlation coefficients (R) of the data sets

\begin{tabular}{|c|c|c|c|c|c|c|c|c|c|c|c|}
\hline \multirow[b]{2}{*}{ Coast area } & \multirow[b]{2}{*}{$\begin{array}{l}\text { Model } \\
\text { No. }\end{array}$} & \multirow[b]{2}{*}{ Inputs } & \multirow[b]{2}{*}{ Outputs } & \multirow[b]{2}{*}{ ANN } & \multicolumn{3}{|c|}{ RMSE } & \multicolumn{4}{|c|}{$\mathbf{R}$} \\
\hline & & & & & Training & Validation & Testing & Training & Validation & Testing & $\begin{array}{l}\text { Whole } \\
\text { data set }\end{array}$ \\
\hline \multirow{4}{*}{$\begin{array}{c}\text { All data of the } \\
\text { lake } \\
\text { (Model 1) }\end{array}$} & Model 1a & \begin{tabular}{|c|} 
Total coliform \\
Faecal streptococci \\
\end{tabular} & $\begin{array}{c}\text { Faecal } \\
\text { coliform }\end{array}$ & $2-2-1$ & 74.859 & 40.435 & 64.555 & 0.755 & 0.866 & 0.944 & 0.77 \\
\hline & Model 1b & \begin{tabular}{|c|} 
Total coliform \\
Faecal streptococci \\
\end{tabular} & $\begin{array}{c}\text { Faecal } \\
\text { coliform }\end{array}$ & $2-5-1$ & 61.829 & 71.010 & 29.998 & 0.843 & 0.801 & 0.948 & 0.84 \\
\hline & Model 1c & Total coliform & Faecal & $1-1-1$ & 80.205 & 74.946 & 53.999 & 0.701 & 0.758 & 0.791 & 0.71 \\
\hline & Model 1d & Total coliform & coliform & $1-3-1$ & 76.559 & 98.575 & 19.931 & 0.766 & 0.635 & 0.833 & 0.76 \\
\hline \multirow{3}{*}{$\begin{array}{c}\text { Göllüce Public } \\
\text { Beach } \\
\text { (Model 2) }\end{array}$} & Model 2b & \begin{tabular}{|c|} 
Total coliform \\
Faecal streptococci \\
\end{tabular} & $\begin{array}{c}\text { Faecal } \\
\text { coliform }\end{array}$ & $2-5-1$ & 86.518 & 14.042 & 89.323 & 0.753 & 0.998 & 0.943 & 0.80 \\
\hline & Model 2c & Total coliform & Faecal & $1-1-1$ & 74.568 & 206.662 & 88.096 & 0.679 & 0.990 & 0.971 & 0.69 \\
\hline & Model 2d & Total coliform & coliform & $1-3-1$ & 85.081 & 70.479 & 50.687 & 0.793 & 0.880 & 0.927 & 0.79 \\
\hline & Model 3a & \begin{tabular}{|c|} 
Total coliform \\
Faecal streptococci \\
\end{tabular} & $\begin{array}{c}\text { Faecal } \\
\text { coliform }\end{array}$ & $2-2-1$ & 65.290 & 32.746 & 37.764 & 0.842 & 0.999 & 0.899 & 0.85 \\
\hline $\begin{array}{l}\text { İnciralt1 Public } \\
\text { Beach }\end{array}$ & Model 3b & \begin{tabular}{|c|} 
Total coliform \\
Faecal streptococci \\
\end{tabular} & $\begin{array}{c}\text { Faecal } \\
\text { coliform }\end{array}$ & $2-5-1$ & 55.068 & 33.122 & 104.545 & 0.817 & 0.985 & 0.998 & 0.86 \\
\hline & Model 3d & Total coliform & coliform & $1-3-1$ & 61.428 & 24.584 & 132.438 & 0.785 & 0.883 & 1.000 & 0.78 \\
\hline & Model 4a & \begin{tabular}{|c|} 
Total coliform \\
Faecal streptococci \\
\end{tabular} & $\begin{array}{l}\text { Faecal } \\
\text { coliform }\end{array}$ & $2-2-1$ & 27.567 & 16.169 & 174.660 & 0.659 & 0.883 & 0.998 & 0.59 \\
\hline $\begin{array}{l}\text { Darka Holiday } \\
\text { Village } \\
\text { (Model 4) }\end{array}$ & Model 4b & \begin{tabular}{|c|} 
Total coliform \\
Faecal streptococci \\
\end{tabular} & $\begin{array}{c}\text { Faecal } \\
\text { coliform }\end{array}$ & $2-5-1$ & 29.681 & 11.991 & 11.371 & 0.947 & 0.999 & 0.982 & 0.95 \\
\hline & Model 4c & Total coliform & Faecal & $1-1-1$ & 62.617 & 50.989 & 13.630 & 0.645 & 0.694 & 0.930 & 0.63 \\
\hline & Model 4d & Total coliform & coliform & $1-3-1$ & 25.872 & 9.532 & 12.136 & 0.949 & 0.907 & 0.956 & 0.95 \\
\hline & Model 5a & \begin{tabular}{|c|} 
Total coliform \\
Faecal streptococci \\
\end{tabular} & $\begin{array}{l}\text { Faecal } \\
\text { coliform }\end{array}$ & $2-2-1$ & 60.452 & 48.69257 & 115.34 & 0.769 & 0.968 & 0.978 & 0.79 \\
\hline $\begin{array}{l}\text { Orhangazi } \\
\text { Public Beach } \\
\text { (Model 5) }\end{array}$ & Model 5b & \begin{tabular}{|c|} 
Total coliform \\
Faecal streptococci \\
\end{tabular} & $\begin{array}{c}\text { Faecal } \\
\text { coliform }\end{array}$ & $2-5-1$ & 18.9066 & 31.68544 & 42.662 & 0.986 & 0.975 & 0.999 & 0.98 \\
\hline & Model 5c & Total coliform & Faecal & $1-1-1$ & 66.6663 & 63.32148 & 73.752 & 0.756 & 0.990 & 0.976 & 0.80 \\
\hline & Model 5d & Total coliform & coliform & $1-3-1$ & 75.671 & 24.87342 & 85.111 & 0.742 & 0.937 & 0.991 & 0.75 \\
\hline
\end{tabular}


Model 1 (All of the Lake data) had more data than model 2. Therefore performance of model 2 might be fallen. Also, it was found that pollution concentrations of Göllüce coast higher than Lake Average. Because it was considered that pollution loads and varieties concentrated in Göllüce coast. For this reason metabolisms and growth rate of microorganisms were affected and model performance dropped.

In model 2-c and d total coliform parameter was selected as input. These models were run efficiently. In model 2-d, hidden neuron numbers were raised. For this reason RMSE values of validation and testing stages decreased and $R$ values of validation and whole data were increased. The structure of $b$ in model 2 like model 1 was the most efficient structure among the others. Increasing of the numbers of input parameters and neurons in hidden layer raised the model 2 performance.

In İnciralt1 coasts "Model 3" a and b structures, total coliform and faecal streptococci parameters were inputs as model 1 and model 2. These model structures were run more efficiently and $\mathrm{R}$ values were bigger than model 1 and model 2 . When model 3 (c and d) compared with model 1 and model 2 it was seen that model $3 \mathrm{c}$ and d structures run better than model $1 \mathrm{c}$ and $\mathrm{d}$ especially model $3 \mathrm{c}$. There was no difference between model $3 \mathrm{c}$ and $\mathrm{d}$. İnciraltı coast was cleaner than Göllüce coast as shown in Table 3. Also, there was cleaner than the lake average in terms of total coliform. Therefore microbial modeling was efficiently due to decrease interactions between pollutants. The raising of neuron numbers of hidden layers in the structures had same number of inputs applied in model 3 (İnciraltı coast) was not enhance model efficiency. The raising of neuron numbers of hidden layers in the structures had same number of inputs in the more contaminated coasts (model 1 and model 2) increased the model efficiency. The raising of input's numbers in the all structures in model 3 enhanced the model efficiency.

In Darka Holiday Village "Model 4" inputs and outputs parameters were like other models. In $\mathrm{a}$ and $\mathrm{b}$ structures RMSE values were less than other models excluding testing value of a structure. For this testing RMSE value R number of whole data set " $a$ " less than other model structures even the smallest $R$ value. Structure $b$ was one of the most efficient running models. When $\mathrm{c}$ and $\mathrm{d}$ were compared structure $\mathrm{d}$ better than $\mathrm{c}$ and other d structures of models. Darka Holiday Village was the cleanest coast in the Lake according to Table 3. The pollution in Darka coast was caused mainly domestic waste water originating from holiday village not from agriculture (BBB, 2016; Municipality of İznik, 2016). Unlike the clean area of İnciralt1, increasing of neurons in hidden layers raised the performances of the structures in the Model 4 had same and different numbers of inputs.

According to comparison of Orhangazi coast "Model 5" with other models RMSE values of structure $b$ smaller than other model's structures and it could be said that the most effective one. $\mathrm{R}$ values of all Model 5 structures were found 0.75 and over. When and $b$ were compared rising of hidden layer number was increased the performance. According to comparison of $\mathrm{c}$ and $\mathrm{d}$ rising of hidden layer number was not increased the performance. In the Orhangazi area which was one of the most contaminated coasts enhancing of inputs and hidden layer numbers provided better model performance. Orhangazi was one of the places where agriculture and industry were the most intense in Bursa (BBB, 2016). In sites co-contaminated with metals and organic compounds, metal toxicity inhibits the activity of organic degrading microorganisms, impacting both their physiology and ecology, thus reducing the rate of biodegradation of the organic compounds (Said and Lewis, 1991; Roane et al., 2001; Maslin and Maier, 2000). Also, 
faecal contamination and growth of pathogens were associated with environmental parameters such as rainfall, temperature, wind, sunlight or different hydrometeorological and hydrodynamic variables (WHO, 2010).

Model structures experimented in this study had shown that the results of the statistical model might not always be in linear trend and gave results with a small inaccuracy. In addition, all these experiments had shown that to increase the number of neurons in hidden layer had not increased at every turn the model efficiency. Species and number of the input parameters might be more effective in the coasts where cleaner than the others with lower concentrations. However, when the whole models were examined the increasing of numbers of inputs with neurons in the hidden layers raised the model performances at every trial. Thus the structure of " $b$ " was found as the most efficient structure in the all models.

As a result, it was found that all model structures of the 4 coasts and all data of the lake were successfully. $\mathrm{R}$ and RMSE values calculated were in the acceptable range (Soyupak et al., 2003; Brion and Lingireddy, 2003; Yonar and K1lıç, 2014; Mas and Ahlfeld, 2007; Ogwueleka and Ogwueleka, 2010; Radojevic et al., 2013). In water pollution and quality studies when number of data and tests were increased RMSE and MSE values were calculated smaller (Soyupak et al., 2003; Yonar and Kıliç, 2014). Figure 3 displays the observed time series and forecasted values with the model structures. In addition, the corresponding scatter plots are also presented.

\section{Conclusions}

This study is important to support the modeling studies of microbiological parameters and to more effective monitoring can be done by measuring fewer parameters with the predictions made. Because there are limited number of studies in deep lakes this study is original in terms of artificial neural network modeling of coliform bacteria in deep lakes. The ANN structures were successfully used to forecast the faecal coliform concentrations in Göllüce, İnciralt1, Darka, Orhangazi Coasts-Lake İznik. Multilayer feed forward networks were used. This study indicated that a neural network could be used to predict microbial pollution in deep lakes.

In the regions, where point sources of pollution were continuous, the modeling study gave a result with a certain margin of error since they disturb the ecological balance of the environment and therefore change the competitive environment among microorganisms continuously. Besides, the error values (RMSE) of the modeling results of the coasts had more pollution load and pollutant diversity (Göllüce and Orhangazi areas) were found to be higher than the others coasts of Darka and İnciralt1, which are relatively cleaner, since the metabolism of microorganisms was effected by the number and chemical structure of substrates (pollutants), existing in the environment, and depending on this, their rates of growth were affected. This study showed that the use of artificial neural networks to forecast of microbial pollution of lake coasts where wide variety of contaminants (industrial and domestic) was found might not provide accurate results.

For this reason summer and winter data could be assessed separately and together, and repeat of the models by increasing the number of data would enhance the model performance. The effect of neural network structure by changing of inputs and neuron's number of hidden layer on model performance was investigated. This study showed also that increasing the number of inputs together with the neurons in hidden layer raised the performance of each model structure. 

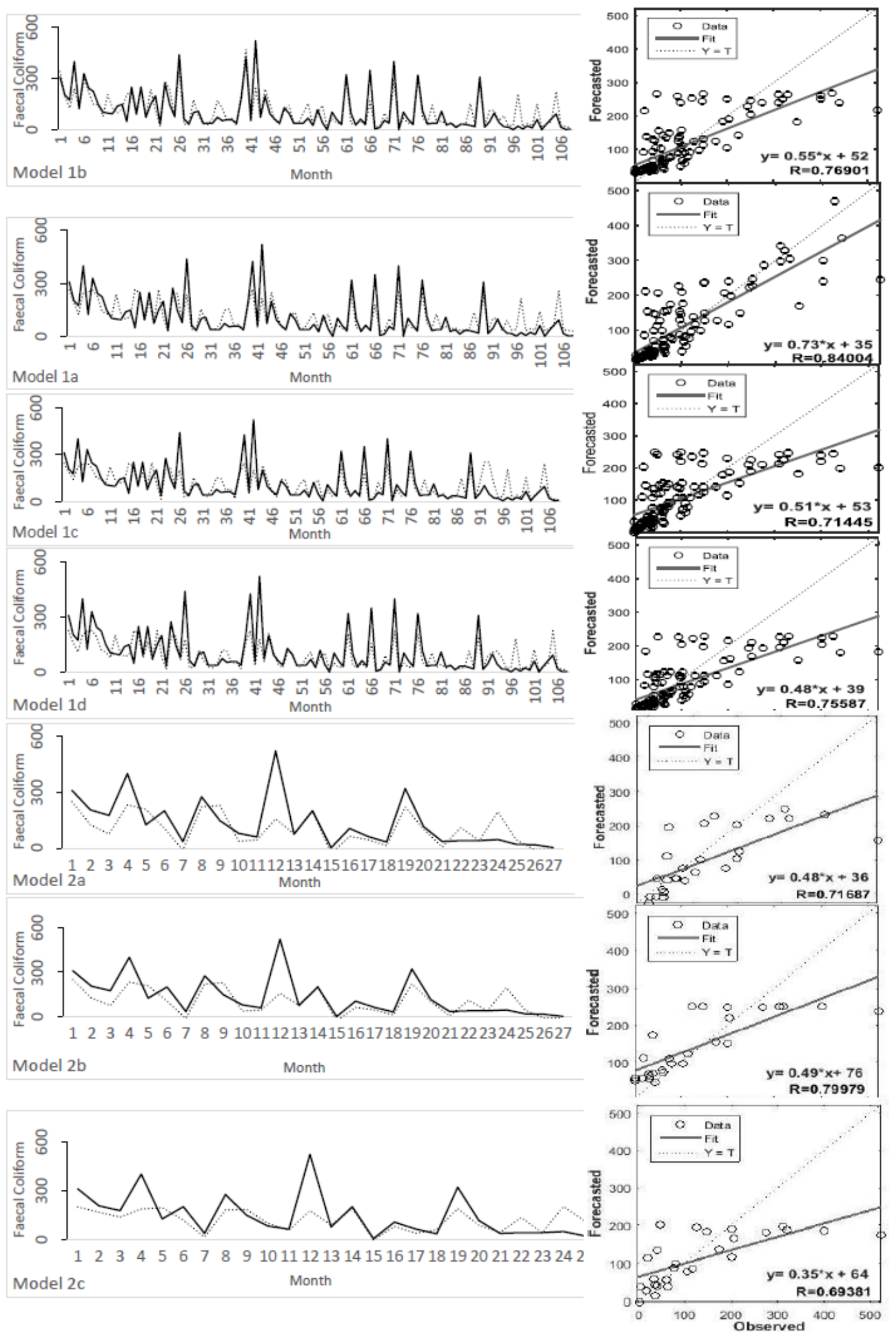

Figure 3. The observed time series and forecasted values with the model structures 

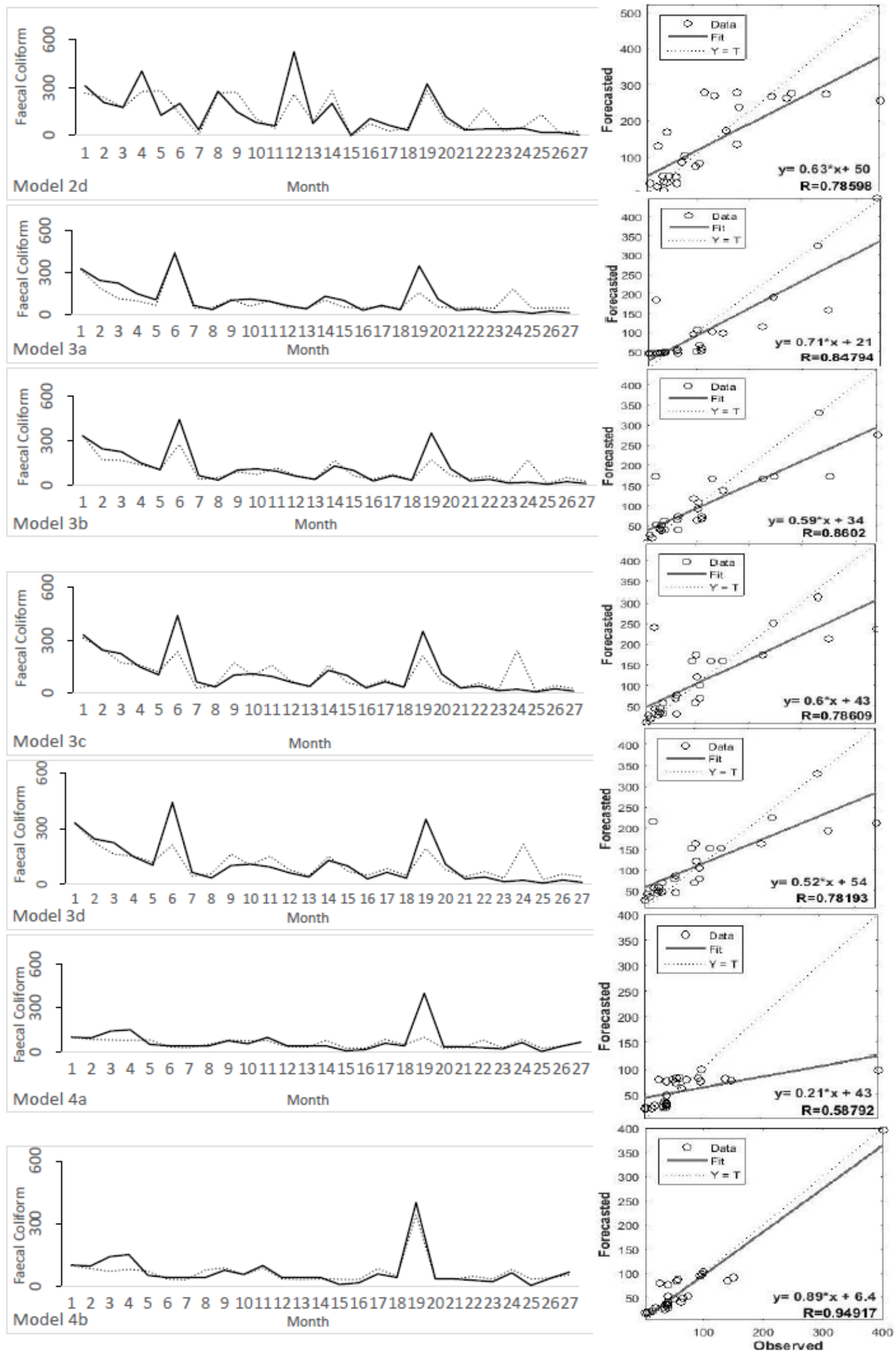

Figure 3. (Continued) The observed time series and forecasted values with the model structures 

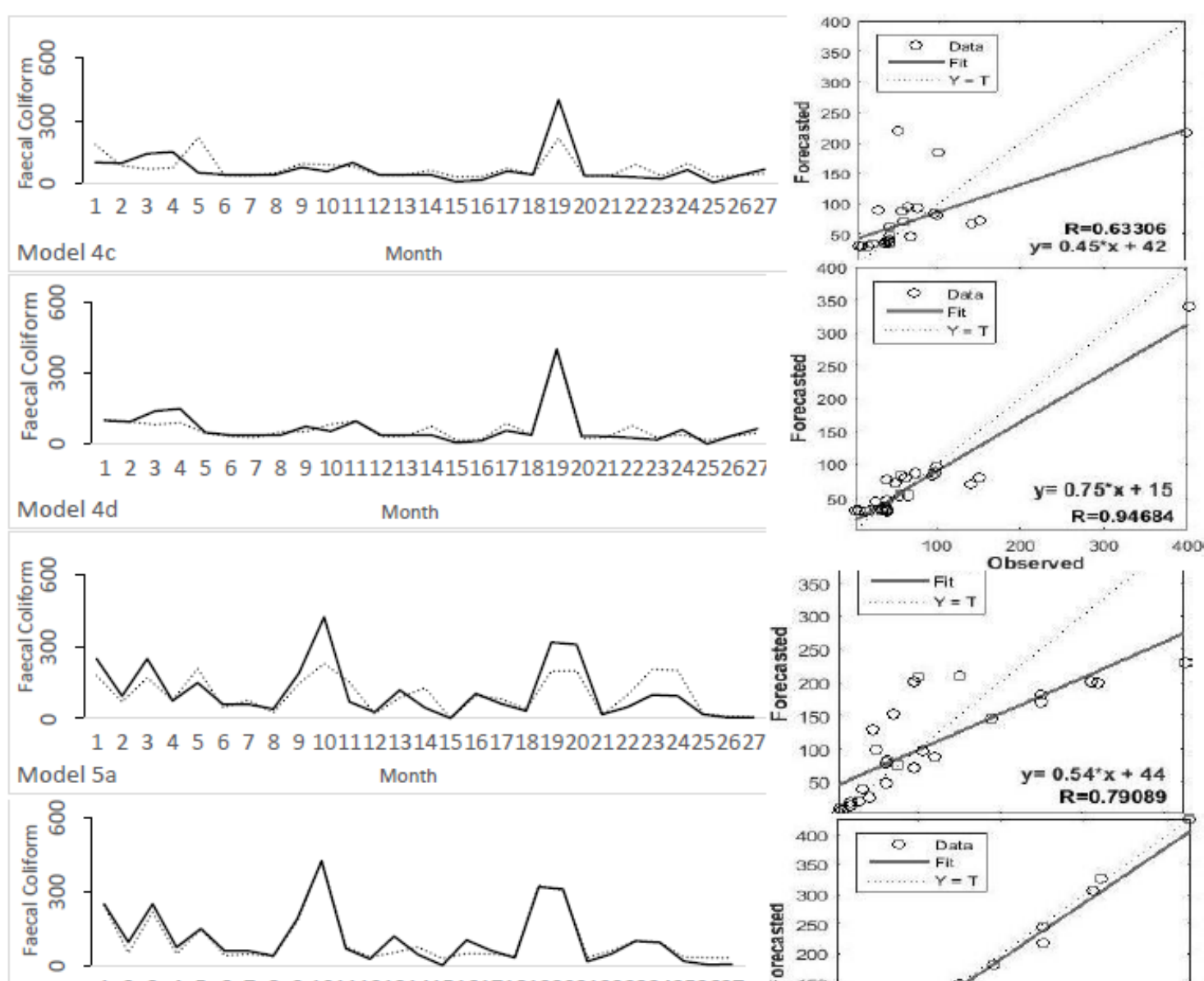

123456789101112131415161718192021222324252627

Model 5b

Month
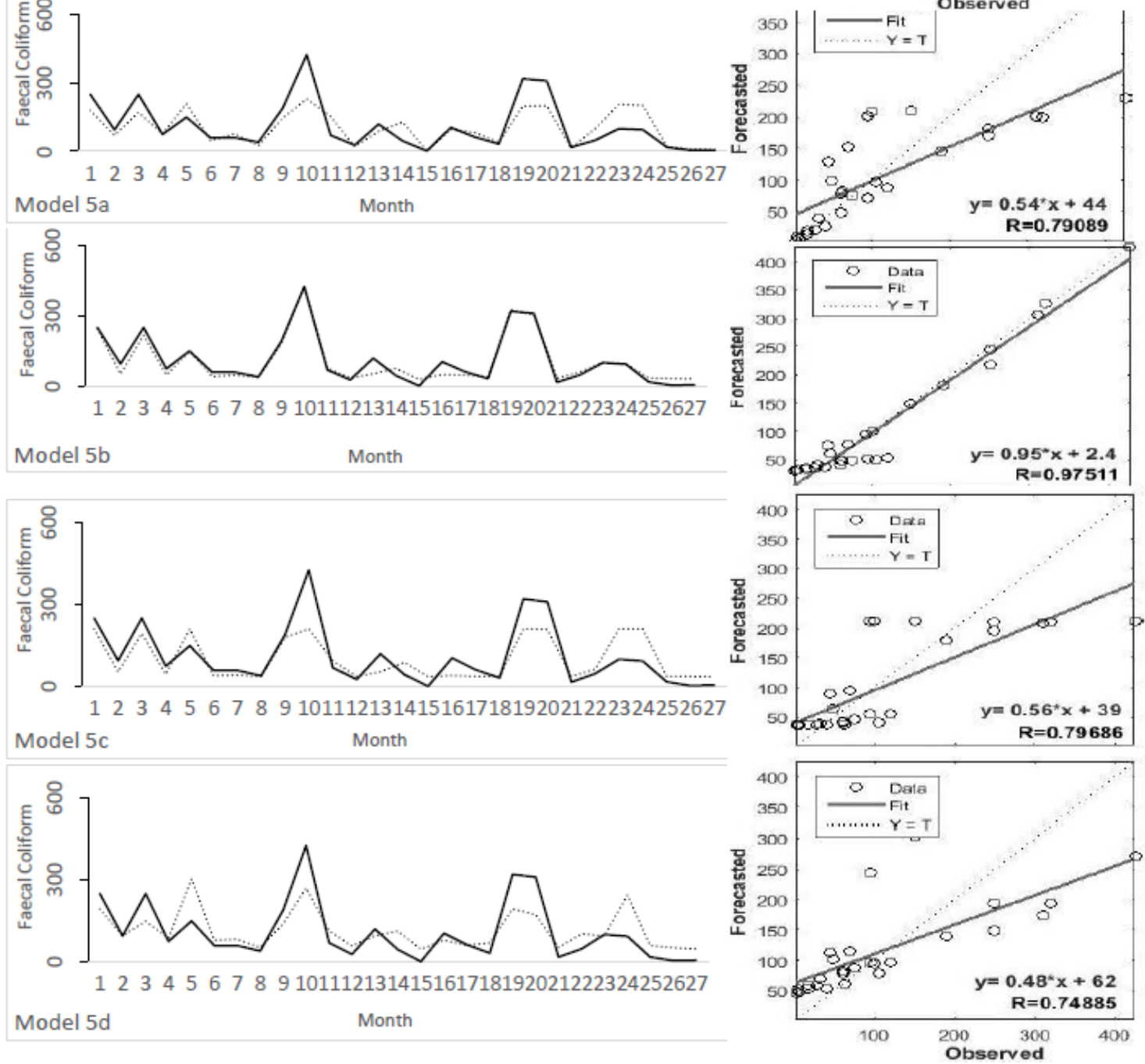

Figure 3. (Continued) The observed time series and forecasted values with the model structures

The development and application of microbial source tracking methods in order to identify sources of faecal pollution could also provide useful additional data. For future studies and providing information to the more effective integrated coastal and basin 
management, it is necessary to simulate pathogen organisms through different statistical and process based dynamic water quality models, using environmental and hydrodynamic parameters in water and in the atmosphere, and compare the model results. Also, different artificial neural network model structures should be applied for different microbiological parameters, and model performances should be examined in the future. In addition to that it will be useful to establish early warning systems, which are very important for public health, on the examined coasts by using the results of the modeling studies. Investigations to improve the knowledge-base of the area would also be of greatest importance to validate coastal and lake models and identify, for example, the role of diffuse sources from animal and agricultural soil origins which could carry human pathogenic bacteria or viruses.

The fact that monitoring and modeling works to protect of Lake İznik has national and international ecological values of in respect to water birds, endemic flora and fauna, tourism, recreation, fishing and agricultural are vitally important for the conservation of natural equilibrium in the world. Consequently continuation and development of modeling studies will be important in the future to provide information to the protection and supervision mechanisms.

Acknowledgements. I would like to thank environmental engineer Tuncay BOZ for computer aids and his valuable research to improve the manuscript.

\section{REFERENCES}

[1] Albay, M., Aykulu, G. (2002): Invertebrate grazer-epiphytic algae interactions on submerged macrophytes in a mesotrophic Turkish lake. - TrJFAS 19: 247-258.

[2] Alberts, B., Johnson, A., Lewis, J. (2002): Introduction to Pathogens. Molecular Biology of the Cell. - Garland Science, New York.

[3] Akçaalan, R., Köker, L., Oğuz, A., Spoof, L., Meriluoto, J., Albay, M. (2014): First report of cylindrospermopsin production by two cyanobacteria (Dolichospermum mendotae and Chrysosporum ovalisporum) in Lake Iznik, Turkey. - Toxins 6: 31733186.

[4] Akkoyunlu, A., Altun, H., Cigizoglu, H. K. (2011): Depth-integrated estimation of dissolved oxygen in a lake. - Journal of Environmental Engineering 137(10): 961-967.

[5] Akpınar, E., Bulut, Y. (2010): Ülkemizde Alternatif Turizm Bir Dalı Olan Ekoturizmi Çeşitlerinin Bölgelere Göre Dağılımı ve Uygulama Alanları. - III. Ulusal Karadeniz Ormanc1lk Kongresi, IV. 1575-159.

[6] APHA (1992): Standard Methods for the Examination of Water and Wastewater, 18th ed. - APHA, Washington DC.

[7] Arvin, E., Jensen, B., Gundersen, A. (1989): Substrate interactions during aerobic biodegradation of benzene. - Applied and Environmental Microbiology 55: 3221-3225.

[8] Basar, H., Çelik, H., Turan, M., Katkat, V. (2002): İznik Yöresinde Sulamada Kullanılan Değişik Su Kaynaklarının Kalite Özelliklerinin Belirlenmesi. - Tarım Bilimleri Dergisi 83: 212-217.

[9] Başar, H., Gürel, S., Katkat, A. V. (2004): Contents of heavy metals in the Lake İznik basin soils irrigated with various water resources (in Turkish). - Uludağ Üniversitesi Ziraat Fakültesi Dergisi 18(1): 93-104.

[10] BBB (2016): Bursa Metropolitan Municipality. - http://www.bursa.bel.tr.

[11] Belayneh, A., Adamowski, J. (2012): Standard precipitation index drought forecasting using neural networks, wavelet neural networks, and support vector regression. - Applied Computational Intelligence and Soft Computing Article ID 794061: 13. 
[12] BGPEFD (2008): Republic of Turkey Bursa Governorship Provincial Environment and Forestry Directorate, Environmental Impact Assessment and Planning Branch Directorate. - BGPEFD, Bursa, Turkey.

[13] Brion, G. M., Lingireddy, S. (2003): Artificial neural network modeling: a summary of successful applications relative to microbial water quality. - Water Science and Technology 47: 235-240.

[14] BUSKİ (2016): Bursa Water and Sewerage Administration İznik Branch Office. http://www.buski.gov.tr/tr/icerik/iznik_sube_mudurlugu_554.

[15] Casadevall, A., Pirofski, L. (2014): Ditch the term pathogen. Comment. - Nature Paper 5167530: 165-6.

[16] Cordier, M., Agúndez, J. P., Hecq, W., Hmaide, B. (2014): A guiding framework for ecosystem services monetization in ecological-economic modeling. - Ecosysl. Serv. 8: 86-96.

[17] Demirci, Ö. S., Can, T. (2015): Determination of Swimming Water Quality of Bursa Coasts (in Turkish). - Uludağ University Engineering Faculty Undergraduate Project.

[18] Efe, Ö., Kaynak, O. (2002): Yapay Sinir Ağları ve Uygulamaları. - Boğaziçi Üniversitesi Yayınları Basım No: 696, İstanbul.

[19] Egli, T. (1995): The ecological and physiological significance of the growth of heterotrophic microorganisms with mixturers of subststrates. - Advances in Microbial Ecology 14: 305-386.

[20] Gürün., S., Kımıran-Erdem, A. (2013): Ayamama Deresi'nin Marmara Denizi’ne Deşarj Alalımdaki Bakteriyolojik Kirlilik Düzeyinin İncelenmesi. - Ekoloji Dergisi 2286: 48-57.

[21] Hagan, M., Menhaj, M. (1994): Training feedforward networks with the Marquardt algorithm. - IEEE Trans. Neural Netw. 5: 989-993.

[22] Haykin, S. (1999): Neural Networks: a Comprehensive Foundation. - Prentice Hall, Upper Saddle River, NJ, USA.

[23] Hornik, K. (1991): Approximation capabilities of multilayer feedforward network. Neural Networks 4: 251-257.

[24] Karadeniz, N., Trrıl, A., Baylan, E. (2009): Wetland management in Turkey: Problems, achievements and perspectives. - African Journal of Agricultural Research 4(11): 11061119.

[25] Karul, C., Soyupak, S., Cilesiz, A. F., Akbay, N., Germen, E. (2000): Case studies on the use of neural networks in eutrophication modeling. - Ecological Modeling 134: 145-152.

[26] Keskin, M. E., Terzi, Ö., Taylan, E. D., Küçükyaman, D. (2009): Meteorological drought analysis using data-driven models for the Lakes District, Turkey. - Hydrological Sciences 54(6): 1114-1124.

[27] Keskin, M. E., Terzi, Ö., Taylan, E. D., Küçükyaman, D. (2011): Meteorological drought analysis using artificial neural networks. - Scientific Research and Essays 621: 44694477.

[28] Kim, T. W., Valdes, J. B. (2003): Nonlinear model for drought forecasting based on a conjunction of wavelet transforms and neural networks. - Journal of Hydrologic Engineering 86: 319-328.

[29] Klečka, G., Maier, W. (1988): Kinetics of microbial growth on mixtures of pentachlorophenol and chlorinated aromatic compounds. - Biotechnol. Bioeng. 31: 328335 .

[30] LGP

(2016): Local Governments

Portal. http://www.yerelnet.org.tr/koyler/koy.php?koyid=240459.

[31] Mas, D., Ahlfeld, D. (2007): Comparing artificial neural networks and regression models for predicting fecal coliform concentrations. - Hydrologic Sciences Journal 524: 713-731.

[32] Maslin, P., Maier, R. (2000): Rhamnolipid enhanced mineralization of phenanthrene in organic metal co-contaminated soils. - Bioremed. J. 4: 295-308.

[33] MATLAB (2015): Getting Started Guide R2015b. - www.mathworks.com. 
[34] Meyer, J., Marcus, M., Bergman, H. (1984): Inhibitory interactions of aromatic organics during microbial degradation. - Environ. Toxicol. Chem. 3: 583-587.

[35] Mishra, A. K., Desai, V. R. (2006): Drought forecasting using feed-forward recursive neural network. - Ecological Modeling 198: 127-138.

[36] Morid, S., Smakhtin, V., Bagherzadeh, K. (2007): Drought forecasting using artificial neural networks and time series of drought indices. - International Journal of Climatology 2715: 2103-2111.

[37] Neelakantan, T. R., Lingireddy, S., Brion, G. M. (2002): Effectiveness of different artificial neural network training algorithms in predicting protozoan risks in surface waters. - Journal of Environmental Engineering 1286: 533-542.

[38] NNMP (2016): Neural Network Modeling Platforms. http://www.neuralware.com/index.php/frequently-asked-questions.

[39] NRC (2004): Indicators for Waterborne Pathogens. - National Academies Press. Washington, DC.

[40] Oğuztürk, G. (2010): Kızılırmak Havzası'nda SYİ ile Kuraklık Analizi ve YSA Yöntemi İle Kuraklık Tahmini (in Turkish). - Master's Thesis, Kırıkkale Üniversity, Graduate School of Natural and Applied Sciences, Department of Civil Engineering, Kirıkkale.

[41] Ogwueleka, T. C., Ogwueleka, F. N. (2010): Data mining application in predicting Cryptosporidium spp. Oocysts and Giardia spp. Cysts concentrations in rivers. - Journal of Engineering Science 53: 342-349.

[42] Okkan, U., Mollamahmutoğlu, A. (2010): Yiğitler Çayı Günlük Akımlarının Yapay Sinir Ağları ve Regresyon Analizi ile Modellenmesi (in Turkish). - Journal of Science and Technolohy of Dumlupınar University 23: 33-48.

[43] Okpokwasili, G. C., Nweke, C. O. (2005): Microbial growth and substrate utilization kinetics. - African Journal of Biotechnology 5: 305-307.

[44] Oktem, Y. A., Gumus, M., Yilmaz, G. B. (2012): The potential sources of pollution affecting the water quality of Lake İznik. - International Journal of Electronics, Mechanical and Mechatronics Engineering 2(3): 225-232.

[45] Öztürk, K., Alpar, B., Adatepe, F. Demirel, S. (2005): İznik Gölü kuvarterner stratigrafi sinin ön (sı̆̆ sismik) değerlendirilmesi (in Turkish). - Turkey Quaternary Symposium TURQUA-V, 118-120.

[46] Özuluğ, M., Altun, Ö., Meriç, N. (2005): On the fish fauna of lake İznik Turkey. Turkish Journal of Zoology 29: 371-375.

[47] Partal, T., Kişi, Ö. (2007): Wavelet and neuro-fuzzy conjunction model for precipitation forecasting. - Journal of Hydrology 3421(2): 199-212.

[48] Principe, J. C., Euliano, N. R., Lefebvre, W. C. (1999): Neural and Adaptive Systems: Fundamentals through Simulations. - Wiley, New York.

[49] Radojevic, I. D., Čomić, L., Rankovic, V., Topuzovic, M. D. (2013): Applying neural networks for predicting the facultative oligotrophic bacteria in two reservoirs with different trophic state. - Journal of Environmental Protection and Ecology 141: 55-63.

[50] RAMSAR (2007): Integrating Wetland Conservation and Wise Use into River Basin Management. Handbook 7. River Basin Management. - Ramsar Handbooks for the Wise Use of Wetlands. Ramsar Convention Secretariat, Gland, Switzerland.

[51] Rankovic, V., Radulovic, J., Radojevic, I., Ostojic, A., Comic, L. (2010): Neural network modeling of dissolved oxygen in the Gruža reservoir, Serbia. - Ecological Modelling 221: 1239-1244.

[52] Reimer, E., Sodoudi, S. (2004): Climate model for the catchment area of the Elbe river with neuro-fuzzy method. - EMS Annual Meeting Abstracts, European Meteorological Society. Nice, France.

[53] Roane, T., Josephson, K., Pepper, I. (2001): Microbial cadmium detoxification allows remediation of co-contaminated soil. - Applied Environmental Microbiology 67: 32083215 . 
[54] Saéz, P., Rittmann, B. (1993): Biodegradation kinetics of a mixture containing a primary substrate phenol and an inhibitory cometabolite 4-chlorophenol. - Biodegradation 41: 321.

[55] Said, W., Lewis, D. (1991): Quantitative assessment of the effects of metals on microbial degradation of organic chemicals. - Applied Environmental Microbiology 57: 14981503.

[56] Şen, Z. (2004): Yapay Sinir Ağları İlkeleri. - Turkey Water Foundation Publications. İstanbul.

[57] Soyupak, S., Karaer, F., Gurbüz, H., Kivrak, E., Sentürk, E., Yazici, A. (2003): A neural network-based approach for calculating dissolved oxygen profiles in reservoirs. - Neural Computing and Applications 12: 166-172.

[58] Soyupak, S., Muhametoğlu, A., Muhametoğlu, H. (2006): Rezervuarlarda Su Kalitesi Tahmininde Kullanılan Modeller. - 1st Fishery and Reservoir Management Symposium, Antalya, Turkey.

[59] TÜRÇEV (2013): Eco-school and Young Reporters for the Environment. - Turkish Environmental Education Foundation. http://www.turcev.org.tr/.

[60] Ülgen, U. B., Franz, S. O., Biltekin, D., Çagatay, M. N., Roeser, P. A., Doner, L., Thein, J. (2012): Climatic and environmental evolution of Lake İznik (NW Turkey) over the last 4700 years. - Quaternary International 274: 88-101.

[61] Viehberg, F. A., Ülgen, U. B., Damc1, E., Franz, S. O., Ön, S. A., Roeser, P. A., Çağatay, M. N., Litt, T., Melles, M. (2012): Seasonal hydrochemical changes and spatial sedimentological variations in Lake Iznik (NW Turkey). - Quaternary International 274: $102-111$.

[62] WHO (2010): Safe Management of Shellfish and Harvest Waters (G. Rees, K. Pond, D. Kay, J. Bartram, J. S. Domingo, eds.). - IWA Publishing, London.

[63] Wu, W., Dandy, G. C., Maier, H. R. (2014): Protocol for developing ANN models and its application to the assessment of the quality of the ANN model development process in drinking water quality modelling. - Environmental Modelling and Software 54: 108-127.

[64] WWF (2011): Protection of Turkey's Wetlands Problems and Solution Suggestions. World Wildlife Fund Turkey Information Note.

[65] Yağc1, M. A., Ustaoğlu, M. R. (2012): Zooplankton fauna of Lake İznik Bursa, Turkey. Turk Journal of Zoology 363: 341-350.

[66] Yonar, T., Yalili Kilic, M. (2014): Chemical oxygen demand and color removal from textile wastewater by $\mathrm{UV} / \mathrm{H}_{2} \mathrm{O}_{2}$ using artificial neural networks. - Water Environment Research 86: 2159-2165.

[67] YSKY (2006): Turkish Swimming Water Quality Regulation 76/160/AB. - 09.01.2006. Date and 26048 Official Newspaper. Ankara. 